JOURNAL OF NURSING PRACTICE AND EDUCATION

VOL. 01 NO. 02, JUNI 2021

DOI: $10.34305 / J N P E . V 112.292$
Ciptaan disebarluaskan di bawah

Lisensi Creative Commons Atribusi-

NonKomersial-BerbagiSerupa 4.0

Internasional.

\title{
HUBUNGAN ANTARA TINGKAT PENGETAHUAN IBU BALITA TENTANG PERILAKU HIDUP BERSIH DENGAN KEJADIAN DIARE PADA BALITA DI PUSKESMAS KLUWUT KECAMATAN BULAKAMBA KABUPATEN BREBES TAHUN 2018
}

\author{
Rosmalia Kamil, Olivia Fujiyanti \\ STIKes Brebes \\ rosemulyawan@gmail.com
}

\begin{abstract}
Abstrak
Diare merupakan salah satu penyakit infeksi yang menyebabkan kematian pada bayi serta anak balita. Diare adalah buang air besar sebanyak tiga kali atau lebih dalam satu hari dengan konsistensi cair. Diare masih menjadi masalah untuk saat ini yang sulit ditanggulangi.

Jumlah penderita diare pada balita di Puskesmas Kluwut Kecamatan Bulakamba Kabupaten Brebes Tahun 2016 sebanyak 1026 (9,13\%) kasus, sedangkan Tahun 2017 Kasus diare pada balita 1060 (9,38\%) kasus. Penelitian ini bertujuan untuk mengetahui hubungan antara tingkat pengetahuan ibu balita tentang perilaku hidup bersih dengan kejadian diare pada balita di Puskesmas Kluwut Kecamatan Bulakamba Kabupaten Brebes Tahun 2018.

Penelitian ini merupakan jenis penelitian survey analitik, menggunakan pendekatan case control. Populasi penelitian ini yaitu 118 responden. Sampel penelitian ini terdiri dari 59 ibu yang mempunyai anak balita menderita diare dan 59 ibu yang mempunyai anak balita tidak menderita diare. Data yang digunakan adalah data sekunder serta data primer. Teknik sampling menggunakan random sampling. Analisis data dilakukan menggunakan analisis univariat dan bivariat, sedangkan teknik analisis data yang digunakan adalah static koefisien kontingensi dan perhitungan Odds Ratio (OR).

Hasil analisis statistik dengan teknik static koefisien kontingensi menunjukkan nilai $\rho=$ 0,003 dan $\mathrm{OR}=3,136$ dengan CI 95\% $=1,463<\mathrm{OR}<3,136$. Nilai $\rho<0,05$ dapat diinterpretasikan secara statistik bahwa terdapat hubungan yang signifikan antara tingkat pengetahuan ibu balita tentang perilaku hidup bersih dengan kejadian diare pada balita. Sehingga Tingkat pengetahuan ibu yang buruk tentang perilaku hidup bersih menjadi faktor risiko kejadian diare pada balita.
\end{abstract}


JOURNAL OF NURSING PRACTICE AND EDUCATION

VOL. 01 NO. 02, JUNI 2021

DOI: $10.34305 / J N P E . V 112.292$
Ciptaan disebarluaskan di bawah

Lisensi Creative Commons Atribusi-

NonKomersial-BerbagiSerupa 4.0

Internasional.

Kesimpulan penelitian ini adalah bahwa tingkat pengetahuan buruk pada kelompok kasus sebanyak 42 responden $(35,6 \%)$ lebih banyak bila dibandingkan dengan kelompok kontrol yang hanya 26 responden $(22,0 \%)$ sedangkan tingkat pengetahuan baik pada kelompok kasus hanya 17 responden $(14,4 \%)$, lebih sedikit dibandingkan dengan kelompok kontrol sebanyak 33 responden $(28,0 \%)$. Sedangkan saran untuk tenaga kesehatan diharapkan lebih meningkatkan pelayanan kesehatan, penyuluhan tentang perilaku hidup bersih, pencegahan penyakit diare di puskesmas, PKD dan posyandu untuk menekan kasus kejadian diare pada balita.

Kata Kunci : Tingkat Pengetahuan, Perilaku Hidup Bersih, Diare, Case Control

\section{Pendahuluan}

Diare merupakan salah satu penyakit infeksi yang menyebabkan kematian pada bayi serta anak balita (Pusat Data dan Informasi Kementrian Kesehatan RI, 2011). Diare adalah buang air besar sebanyak tiga kali atau lebih dalam satu hari dengan konsistensi cair. Diare masih menjadi masalah untuk saat ini yang sulit ditanggulangi.

Di Indonesia menurut Kementrian Kesehatan Republik Indonesia (2019), diare merupakan penyakit endemis dan berpotensi Kejadian Luar Biasa (KLB) disertai dengan kematian. Pada tahun 2018 terjadi 10 kali KLB yang tersebar di 8 provinsi, 8 kabupaten/kota. Jumlah penderita 756 orang dan kematian 36 orang (CFR 4,76\%). Angka kematian (CFR) diharapkan 1\%), dan pada tahun 2018 CFR Diare mengalami peningkatan dibanding tahun 2017 yaitu menjadi $4,76 \%$.

Jumlah kasus diare di Provinsi Jawa Tengah secara keseluruhan mencapai 728.009 penderita. Proporsi kasus diare di Jawa Tengah tahun 2016 sebesar 68,9\%, meningkat bila dibandingkan dengan proporsi tahun 2015 yaitu 67,7\%. Kasus diare pada balita rata-rata per tahunnya mencapai $40 \%$ dengan jumlah kasus balita mencapai 291.203 penderita. Hal ini menunjukkan bahwa kasus diare pada balita di Provinsi Jawa Tengah masih tetap tinggi dibandingkan dengan golongan usia lainnya. Kabupaten/kota dengan angka penemuan kasus diare tertinggi adalah Kota Tegal yaitu $221,6 \%$ sedangkan kabupaten/kota dengan angka penemuan terendah adalah Grobogan 
JOURNAL OF NURSING PRACTICE AND EDUCATION

VOL. 01 NO. 02, JUNI 2021

DOI: $10.34305 / J N P E . V 112.292$

yaitu 9,9\% (Dinas Kesehatan Provinsi Jawa Tengah, 2017).

Menurut (Dinas Kesehatan Kabupaten Brebes, 2018), cakupan penemuan angka diare pada Tahun 2017 sebesar 43538 (11,33\%) kasus. Jumlah kasus diare pada balita setiap tahunnya rata-rata di atas $40 \%$. Ini menunjukan bahwa kasus diare pada balita masih tetap tinggi dibanding golongan umur lainnya.

Menurut Dinas Kesehatan Provinsi Jawa Tengah, 2018), jumlah Rumah Tangga di Puskesmas Kluwut yang dipantau PHBS sebanyak $13686(83,12 \%)$ RT, sedangkan yang ber PHBS sebanyak 9544 (69,75\%). Kasus diare pada balita di Puskesmas Kluwut Tahun 2016 sebanyak 1026 (9,13\%) kasus, sedangkan Tahun 2017 Kasus diare pada balita 1060 (9,38\%) kasus. Untuk menekan angka kesakitan diadakan penyuluhan di puskesmas posyandu dan setiap pertemuan PKK Desa dan kader UPGK.

Menurut Brandt et al., (2015), ada beberapa faktor penyebab diare yaitu faktor infeksi (bakteri, virus, parasit), gangguan penyerapan makanan dan minuman di usus seperti penyerapan karbohidrat, lemak dan protein. Pada faktor makanan seperti
Ciptaan disebarluaskan di bawah Lisensi Creative Commons AtribusiNonKomersial-BerbagiSerupa 4.0 Internasional.

makanan basi, beracun, alergi terhadap makanan, faktor psikologis seperti cemas, takut dan terkejut. Sedangkan penyebab lainnya adalah rotavirus, kualitas air minum, kebersihan dan sanitasi (Dar et al., 2017). Diare berdampak buruk jika tidak segera diatasi. Apabila diare tidak teratasi, maka akan dapat menimbulkan kejang, gangguan irama jantung sampai pendarahan di otak, dan apabila dehidrasi (kekurangan cairan tubuh) berat bisa menyebabkan kematian (Barr \& Smith, 2014).

Suharyono (1999:56) dalam buku Nursalam (2008) menjelaskan sebagai akibat dari diare akut maupun kronis yaitu dapat terjadi kehilangan air dan elektrolit (terjadi dehidrasi), hipoglikemia, gangguan gizi, gangguan sirkulasi, komplikasi, kejang terjadi pada dehidrasi hipertonik, dan malnutrisi energi protein (akibat muntah dan diare jika lama atau kronik).

Berdasarkan paparan tentang berbagai masalah dan penyebab terjadinya diare diatas, maka peneliti merasa tertarik untuk melakukan penelitian yaitu tentang "Hubungan Antara Tingkat Pengetahuan Ibu Balita Tentang Perilaku Hidup Bersih Dengan Kejadian Diare Pada Balita Di 
JOURNAL OF NURSING PRACTICE AND EDUCATION

VOL. 01 NO. 02, JUNI 2021

DOI: $10.34305 / J N P E . V 1 I 2.292$

Puskesmas Kluwut Kecamatan Bulakamba Kabupaten Brebes Tahun 2018”.

\section{Metode}

Penelitian ini menggunakan survey analitik. Menurut Notoatmodjo (2012), penelitian jenis survey analitik yaitu riset epidemiologi yang bertujuan untuk memperoleh penjelasan faktor-faktor risiko dan penyebab penyakit. dan pendekatan penelitian yang digunakan adalah retrospektif dengan studi observasional case control. Populasi dalam penelitian ini adalah semua ibu yang mempunyai anak balita yang terkena diare dengan jumlah 70 dan semua ibu yang mempunyai anak balita yang tidak terkena diare di Puskesmas Kluwut Kecamatan Bulakamba Kabupaten Brebes.

Pada penelitian ini menggunakan teknik random sampling yaitu untuk
Ciptaan disebarluaskan di bawah Lisensi Creative Commons Atribusi-

NonKomersial-BerbagiSerupa 4.0 Internasional. menentukan besar sampel (Notoatmodjo, 2010). Sampel pada penelitian ini adalah ibu yang mempunyai anak balita yang terkena diare dengan jumlah 59 yang merupakan sampel untuk kelompok kasus, sedangkan untuk kelompok kontrol juga ada 59 ibu yang mempunyai anak balita yang tidak terkena diare. Dalam penelitian ini digunakan perbandingan 1 : 1 yaitu satu kelompok kasus dengan jumlah 59 responden dibandingkan satu kelompok kontrol dengan jumlah 59 responden. Jadi jumlah responden dalam penelitian ini adalah 118 responden.

\section{Hasil}

Analisis Univariat

Karakteristik responden berdasarkan Tingkat Pengetahuan

\section{Tabel 1. Distribusi responden berdasarkan Tingkat Pengetahuan}

\begin{tabular}{lll}
\hline Tingkat Pengetahuan & Frekuensi & Prosentase $\mathbf{( \% )}$ \\
Buruk & 68 & 57,6 \\
Baik & 50 & 42,4 \\
Total & 118 & 100 \\
\hline
\end{tabular}

Berdasarkan hasil analisis data responden dengan tingkat dengan menunjukan bahwa tingkat pengetahuan ibu pengetahuan buruk sebanyak 68 responden balita tentang perilaku hidup bersih di Puskesmas Kluwut Kecamatan Bulakamba kabupaten Brebes tahun 2018 bahwa (57,6\%), sedangkan dengan pengetahuan baik sebanyak 50 responden $(42,4 \%)$. Dengan demikian secara keseluruhan 
JoURNAL OF NURSING PRACTICE AND EDUCATION

VOL. 01 NO. 02, JUNI 2021

DOI: $10.34305 / J N P E . V 1 I 2.292$
Ciptaan disebarluaskan di bawah

Lisensi Creative Commons Atribusi-

NonKomersial-BerbagiSerupa 4.0

Internasional. menunjukan bahwa tingkat pengetahuan ibu balita tentang perilaku hidup bersih di Puskesmas Kluwut Kecamatan Bulakamba
Kabupaten Brebes tahun 2018 termasuk dalam kategori buruk.

Analisis Bivariat

Tabel 2. Tingkat Pengetahuan Ibu Balita Tentang Perilaku Hidup Bersih Dengan Kejadian Diare

\begin{tabular}{|c|c|c|c|c|c|c|}
\hline \multirow{3}{*}{ Tingkat pengetahuan } & \multicolumn{4}{|c|}{ Subjek Penelitian } & \multirow{2}{*}{\multicolumn{2}{|c|}{ Total }} \\
\hline & \multicolumn{2}{|l|}{ Kasus } & \multicolumn{2}{|c|}{ Kontrol } & & \\
\hline & Jumlah & $\%$ & Jumlah & $\%$ & Jumlah & $\%$ \\
\hline Buruk & 42 & 35,6 & 26 & 22,0 & 68 & 57,6 \\
\hline Baik & 17 & 14,4 & 33 & 28,0 & 50 & 42,4 \\
\hline Total & & & & & 118 & 100,0 \\
\hline $\mathrm{OR}=3,136$ & \multicolumn{4}{|c|}{ CI $95 \%=1,463<$ OR $<6,723$} & \multicolumn{2}{|c|}{ Nilai $p=0,003$} \\
\hline
\end{tabular}

Berdasarkan hasil analisis data didapat bahwa tingkat pengetahuan buruk pada kelompok kasus sebanyak 42 responden $(35,6 \%)$ lebih banyak bila dibandingkan dengan kelompok kontrol yang hanya 26 responden $(22,0 \%)$ sedangkan tingkat pengetahuan baik pada kelompok kasus hanya 17 responden $(14,4 \%)$, lebih sedikit dibandingkan dengan kelompok kontrol sebanyak 33 responden $(28,0 \%)$.

Hasil statistik berdasarkan uji static koefisien kontingensi dengan menggunakan SPSS windows versi 16.0 menunjukkan nilai probabilitas $(\rho)=0,003$ karena $p<0,05$ maka hipotesis nol (Ho) ditolak dan hipotesis kerja (Ha) diterima. Hasil analisis $\mathrm{p}=0,003$ dan Odds Ratio $(\mathrm{OR})=3,136$ dengan Confidence Interval $(\mathrm{CI}) 95 \%=$ $1,463<\mathrm{OR}<6,723$. Nilai $\rho<0,05$ dapat diinterpretasikan secara statistik bahwa ada hubungan yang bermakna antara tingkat pengetahuan ibu balita tentang perilaku hidup bersih dengan kejadian diare pada balita di Puskesmas Kluwut Kecamatan Bulakamba Kabupaten Brebes Tahun 2018. Sehingga tingkat pengetahuan ibu yang buruk tentang perilaku hidup bersih menjadi faktor risiko kejadian diare pada balita. 
JoURNAL OF NURSING PRACTICE AND EDUCATION

VOL. 01 NO. 02, JUNI 2021

DOI: $10.34305 / J N P E . V 1 I 2.292$

Berdasarkan dari perhitungan odds ratio (OR) sebesar 3,136 dapat diketahui bahwa ibu balita dengan tingkat pengetahuan buruk mempunyai risiko 3,136 kali lebih besar terkena diare bila dibandingkan dengan ibu balita ibu dengan tingkat pengetahuan baik.

\section{Pembahasan}

Berdasarkan hasil uji statistic variabel tingkat pengetahuan dan perilaku hidup bersih maka didapatkan hasil:

Karakteristik responden berdasarkan Tingkat Pengetahuan

Penelitian menunjukan bahwa tingkat pengetahuan ibu balita tentang perilaku hidup bersih di Puskesmas Kluwut Kecamatan Bulakamba Kabupaten Brebes tahun 2018 termasuk dalam kategori buruk.

Menurut Notoatmodjo (2012), "Pengetahuan merupakan hasil dari kata tahu, serta ini terjadi setelah orang melakukan pengindraan terhadap suatu objek tertentu. Penginderaan terjadi melalui panca indra manusia, yaitu indra penglihatan, indra pendengaran, indra penciuman, indra perasa dan indra peraba". Sebagian besar pengetahuan manusia diperoleh melalui
Ciptaan disebarluaskan di bawah Lisensi Creative Commons AtribusiNonKomersial-BerbagiSerupa 4.0 Internasional. mata dan telinga. Sedangkan faktor-faktor yang mempengaruhi pengetahuan yaitu: usia, tingkat pendidikan, dan pengalaman.

Pengetahuan itu memiliki sifat logis, dapat diamati dan diukur, serta diperoleh melalui metode ilmiah maka pengetahuan dapat dianggap sebagai ilmu, dengan kata lain pengetahuan itu dapat berkembang menjadi ilmu apabila memenuhi kriteria (Nursalam, 2008).

Pengetahuan merupakan domain yang paling penting dalam membentuk tindakan seseorang (Notoatmodjo, 2012). Menurut teori Green pengetahuan merupakan faktor yang mempermudah terjadinya perilaku (Notoatmodjo, 2010). Oleh karena itu ibu balita harus lebih meningkatkan pengetahuan tentang perilaku hidup bersih untuk mencegah dan mengantisipasi terjadinya diare pada anakanaknya.

Tingkat Pengetahuan Ibu Balita Tentang Perilaku Hidup Bersih Dengan Kejadian Diare

Penelitian menunjukan bahwa ada hubungan yang bermakna antara tingkat pengetahuan ibu balita tentang perilaku hidup bersih dengan kejadian diare pada 
JOURNAL OF NURSING PRACTICE AND EDUCATION

VOL. 01 NO. 02, JUNI 2021

DOI: $\underline{\text { 10.34305/JNPE.V1I2.292 }}$

balita di Puskesmas Kluwut Kecamatan Bulakamba Kabupaten Brebes Tahun 2018.

Sehingga tingkat pengetahuan ibu yang buruk tentang perilaku hidup bersih menjadi faktor risiko kejadian diare pada balita.

Menurut Notoatmodjo (2010), perilaku kesehatan merupakan suatu respons seseorang (organisme) terhadap stimulus dan objek yang berkaitan dengan sakit atau penyakit, sistem pelayanan kesehatan, makanan, minuman, serta lingkungan. Membiasakan perilaku hidup bersih dan sehat yaitu dengan mencuci tangan menggunakan sabun sebelum makan atau setelah memegang benda yang kotor. Dan juga peralatan sumber air untuk bayi, tempat yang digunakan harus bersih agar terhindar dari penyakit diare.

Menurut Badriah (2012), diare yaitu pengeluaran feces yang tidak normal dan cair. Biasanya juga diartikan sebagai buang air besar yang tidak normal dan berbentuk cair dengan frekuensi lebih banyak dari biasanya. Bayi dikatakan terkena diare bila sudah lebih dari 3 kali buang air besar, sedangkan Balita dikatakan diare bila sudah lebih dari 4 kali buang air besar. Penyebab diare yaitu karena faktor cuaca, lingkungan, dan makanan. Perubahan iklim, kondisi
Ciptaan disebarluaskan di bawah Lisensi Creative Commons AtribusiNonKomersial-BerbagiSerupa 4.0 Internasional. (i)(2)

lingkungan kotor, dan kurang memperhatikan kebersihan makanan merupakan faktor utamanya.

Penularan diare umumnya melalui 4F, yaitu Food, Fly, Feces, dan Finger. Pada upaya pencegahan diare meliputi: memberikan ASI, memperbaiki makanan pendamping ASI, menggunakan air bersih yang cukup, mencuci tangan, menggunakan jamban, membuang tinja bayi dengan benar,serta memberikan imunisasi campak karena pemberian imunisasi campak dapat mencegah terjadinya diare yang lebih berat lagi (Kemenkes RI, 2011).

Berdasarkan hasil uji static koefisien kontingensi tentang hubungan antara tingkat pengetahuan ibu balita tentang perilaku hidup bersih dengan kejadian diare diperoleh nilai $\mathrm{X}^{2}>0,05$ dan nilai $\mathrm{p}<0,05$ serta $\mathrm{OR}=$ 3,136 yang berarti bahwa bahwa terdapat hubungan yang bermakna antara tingkat pengetahuan ibu balita tentang perilaku hidup bersih dengan kejadian diare pada balita di Puskesmas Kluwut kecamatan Bulakamba kabupaten Brebes tahun 2018.

Dari hasil penelitian didapatkan bahwa ibu balita yang mempunyai anak balita yang terkena diare lebih banyak dengan pengetahuan buruk. Hal ini sesuai 
JoURNAL OF NURSING PRACTICE AND EDUCATION

VOL. 01 NO. 02, JUNI 2021

DOI: $10.34305 / J N P E . V 112.292$

dengan yang diungkapkan oleh Notoatmodjo (2010), pendidikan akan memberikan pengetahuan sehingga terjadi perubahan perilaku, dan tingkat pengetahuan akan meningkat. Seseorang yang mempunyai sumber informasi lebih banyak pasti akan mempunyai pengetahuan yang luas, sedangkan hal-hal yang pernah dialami akan menambah pengetahuan tentang sesuatu yang bersifat nonformal serta kepercayaan dan sikap sangat mempengaruhi perilaku manusia. Sehingga jelas bahwa tingkat pengetahuan seseorang banyak menentukan sikap, perilaku dan keterampilan dalam mengambil keputusan dan bertindak.

\section{Kesimpulan}

Berdasarkan hasil penelitian mengenai tingkat pengetahuan ibu balita tentang perilaku hidup bersih dengan kejadian diare pada balita di Puskesmas Kluwut kecamatan Bulakamba kabupaten Brebes tahun 2018, maka berdasarkan uji statistik dan analisis data dari setiap variabel didapat hasil sebagai berikut:

Tingkat pengetahuan ibu balita tentang perilaku hidup bersih di Puskesmas Kluwut Kecamatan Bulakamba Kabupaten
Ciptaan disebarluaskan di bawah Lisensi Creative Commons AtribusiNonKomersial-BerbagiSerupa 4.0 Internasional. yaitu 68 responden $(57,6 \%)$ lebih banyak bila dibandingkan dengan responden dengan tingkat pengetahuan baik yang hanya 50 responden $(42,4 \%)$.

Tingkat pengetahuan ibu balita tentang perilaku hidup bersih di Puskesmas Kluwut Kecamatan Bulakamba Kabupaten Brebes dengan tingkat pengetahuan buruk pada kelompok kasus yaitu 42 responden $(35,6 \%)$, lebih banyak bila dibandingkan dengan kelompok kontrol yang hanya 17 responden $(14,4 \%)$.

Berdasarkan hasil analisis statistik menggunakan uji koefisien kontingency diperoleh nilai $\mathrm{P}=0,003$ dan $\mathrm{OR}=3,136$ dengan CI 95\% = 1,463 < OR <6,723. Nilai $\mathrm{P}<0,005$ dapat diinterpretasikan secara statistik bahwa ada hubungan yang bermakna antara tingkat pengetahuan ibu balita tentang perilaku hidup bersih dengan kejadian diare pada balita di Puskesmas Kluwut Kecamatan Bulakamba Kabupaten Brebes tahun 2018.

Berdasarkan dari perhitungan odds ratio (OR) sebesar 3,136 dapat diketahui bahwa ibu balita dengan tingkat pengetahuan buruk mempunyai risiko 3,136 kali lebih besar terkena diare bila 
JOURNAL OF NURSING PRACTICE AND EDUCATION

VOL. 01 NO. 02, JUNI 2021

DOI: $10.34305 / J N P E . V 112.292$

dibandingkan dengan ibu balita ibu dengan tingkat pengetahuan baik.

\section{Saran}

Tenaga kesehatan diharapkan lebih meningkatkan pelayanan kesehatan dan penyuluhan pencegahan penyakit diare di puskesmas, PKD dan posyandu untuk pencegahan dini penyakit diare pada balita dan perilaku hidup bersih. Hasil penelitian ini dapat dijadikan data dasar untuk penelitian selanjutnya.

\section{Daftar Pustaka}

Badriah, D. L. (2012). Metodologi Penelitian Ilmu-Ilmu Kesehatan. Bandung: Multazam.

Barr, W., \& Smith, A. (2014). Acute diarrhea in adults. American Family Physician, 89(3), 180-189.

Brandt, K. G., Antunes, M. M. de C., \& Silva, G. A. P. da. (2015). Diarreia aguda: manejo baseado em evidências. Jornal de Pediatria, 91(6), S36-S43.

Dar, M. J., Ali, H., Khan, A., \& Khan, G. M. (2017). Polymer-based drug delivery: the quest for local targeting of inflamed intestinal mucosa. Journal of Drug Targeting, 25(7), 582-596.

Dinas Kesehatan Kabupaten Brebes. (2018). Profil Kesehatan Kabupaten Brebes Tahun 2017. Dinas Kesehatan Kabupaten Brebes.
Ciptaan disebarluaskan di bawah

Lisensi Creative Commons Atribusi-

NonKomersial-BerbagiSerupa 4.0

Internasional.

(c) ()ㅇㅇ

Dinas Kesehatan Provinsi Jawa Tengah. (2017). Profil Kesehatan Provinsi Jawa Tengah Tahun 2016. Dinas Kesehatan Provinsi Jawa Tengah.

Dinas Kesehatan Provinsi Jawa Tengah. (2018). Profil Kesehatan Provinsi Jawa Tengah Tahun 2017. Dinas Kesehatan Provinsi Jawa Tengah.

Kemenkes RI. (2011). Panduan Sosialisasi Tatalaksana Diare Balita. Jakarta: Direktorat Jenderal Pengendalian Penyakit Dan Penyehatan Lingkungan.

Kementrian Kesehatan Republik Indonesia. (2019). Profil Kesehatan Indonesia 2018. Kementrian Kesehatan Republik Indonesia.

Notoatmodjo, S. (2010). Metodologi Penelitian Kesehatan. Jakarta: rineka cipta.

Notoatmodjo, S. (2012). Promosi Kesehatan dan Perilaku Kesehatan. Jakarta: Rineka Cipta, 45-62.

Nursalam. (2008). Konsep dan Penerapan Metodologi Penelitian Ilmu Keperawatan : Pedoman Skripsi, Tesis, dan Instrumen Penelitian Keperawatan (2nd ed.). Salemba Medika.

Pusat Data dan Informasi Kementrian Kesehatan RI. (2011). Situasi Diare di Indonesia. Kementrian Kesehatan Republik Indonesia. 